\title{
Healthcare Reform: The Rhetoric and the Reality
}

\author{
Michael H. Fox
}

Reading from a newspaper recently, I came across an article entitled Trying the Patience: Health Care Ills at Epidemic Proportions:

Increasingly, the health care system is trying the patience of those who need it. Consumers are coming under the control of unseen and seemingly incomprehensible forces, with the result that they do not have the access to health care they once had. And the reason is cost. Health care is getting more and more expensive, and no one has yet figured out a way to stop the increase.

The article goes on to quote the president of a state medical society and provides further commentary:

"There is now a lot of dissatisfaction. We hear it in the lounges, we hear it in the halls, we hear it all over the place."

While there has been much concern about cost for a decade, the debate has taken on a new seriousness. The system is breaking down, running out of money, losing its ability to provide medical care to more and more people, the experts say.

There are cries for reform, for change, for evolution and more and more for revolution. The cry for some kind of nationally funded health care system that guarantees universal access is growing louder and louder. The problem with the current US health care system . . is that there is no health care system in the United States. Instead, there are five groups - patients, hospitals, doctors, insurance companies, and employers-who have different needs and wants, and different thoughts on how to fulfill those needs and wants. ${ }^{2}$

Sc.D., Associate Professor, Department of Health Policy \& Management, University of Kansas Medical Center.

1. Jeff Cole, Trying the Patience: Health Care Ills at Epidemic Proportions, MILwAUKEE SENTINEL, Jan. 22, 1991, at B1.

2. Id. 
I found this article recently while cleaning out my garage. It was mailed to me by my mother, shortly after it was published in the Milwaukee Sentinel on the morning of Tuesday, January 22, 1991. This was shortly before she had a stroke and subsequently died a few months later from having her congestive heart failure misdiagnosed by stewards of the same health care system she felt I would be interested in reading about. Of course, the article could just as easily have been written today.

Discussing health care reform now is not as easy as it was sixteen years ago or even four years ago, in part because so much of our national discourse has changed. Words now, as often as not, describe actions that appear very different from events that actually occur. The genius behind promoting this new way of communicating is nowhere better revealed than in two of the most telling statistics I found while researching my remarks for the Symposium: first, a CNN news poll suggests that $43 \%$ of Americans still believed, as of the summer of 2006, that Saddam Hussein was behind the events of $9 / 11^{3}$; and second, $31 \%$ more Americans can name the Three Stooges than can name our three arms of government. ${ }^{4}$ In an electorate in which knowledge is poorly valued, information is easily manipulated. While this has always been the case to some degree in my lifetime - "the medium is the message" - this gap between what is being said and what is being done is among the greatest challenges we now face in helping us frame social issues such as health reform.

In this environment, concepts can become blurred beneath the overriding popular beliefs superceding them. Almost four years ago, I spoke at a health care forum in Kansas City, Missouri and shared my vision for an improved health care system in our country, one modeled after those that regard health care as a human right. I discussed the ethical challenge we face living in a country ranked thirty-seventh by the World Health Organization in health system performance, ${ }^{6}$ while having the highest standard of living and percent of gross domestic product spent on health care. I suggested then that even though we could afford to pay farmers in our country close to $\$ 900$ billion over ten years not to grow crops, ${ }^{7}$ even though Business Week quoted an American Academy

3. PollingReport.com, CNN Poll, Aug. 30-Sept. 2, 2006, http://www.pollingreport.com/iraq4. htm (last visited Jan. 26, 2007) [hereinafter CNN].

4. Zogby Int'l Tel. Poll, July 21-27, 2006, at 2-3, http:/www.zogby.com/wfAOL\%20National.pdf [hereinafter Zogby].

5. See MARShall MCluHAN, UNDERSTANDING MEDIA 7-21 (1964) (discussing the effect of media on culture).

6. WORLd HEALTH ORG., THE WORLD HEALTH REPORT 2000: HEALTH SySTEMS: IMPROVING PERFORMANCE 155 (2000), available at http://www.who.int/whr/2000/en/whr00_en.pdf.

7. CONG. BUdget OfFICE, PAY-AS-YOU-Go Estimate, Farm Security and Rural Investment 
of Arts and Sciences estimate of up to $\$ 1.9$ trillion in costs for a then looming conflict in Iraq, ${ }^{8}$ even though proposed tax cuts would deplete another $\$ 2.1$ trillion from our Treasury, ${ }^{9}$ somehow when it came to finding real dollars to invest in our nation's health, costs were always the issue. I closed my comments that day with the statement that, "Quality and accessible health care cannot and should not be an entitled privilege in a society as wealthy as ours. We must act to let our political leaders know that health care for all is as fundamental to our basic values as it is necessary to our basic needs." 10

A brief review of the accompanying articles written by the distinguished speakers at the Kansas Law Review Symposium leaves the impression that our health care system remains troubled, efforts of states such as Massachusetts notwithstanding. Census figures identify nearly forty-seven million Americans-including over eight million childrenwith no health coverage at all in a year, ${ }^{11}$ and almost sixty-seven million without health insurance at some point in a year. ${ }^{12}$ The Institute of Medicine estimates that an average of fifty people die each day because they are uninsured and cannot get the medical care they need. ${ }^{13}$ Closer to home, there are nearly 200,000 persons living in Kansas City without health insurance. ${ }^{14}$ The Kaiser Family Foundation estimates that $12 \%$ of non-elderly persons living in Kansas and $14 \%$ in Missouri have no health care insurance. $^{15}$

Act of 2002 H.R. 2646. 107th Cong. (2002) (enacted), available at http://www.cbo.gov/ftpdocs/ $34 \mathrm{xx} /$ doc 3468/hr2646omb.pdf.

8. Christopher Farrell, The Real Cost of War with Iraq, BusinessWeEK ONLINE, Dec. 13, 2002, http://www.businessweek.com/bwdaily/dnflash/dec2002/nf20021213_2149.htm.

9. CTR. ON Budget \& Policy Priorities, AVailable Budget SuRPlus Is SMALler ThaN MANY REALIZE (2001), http://www.cbpp.org/1-8-0l bud.pdf.

10. Michael H. Fox, Address at All Souls Unitarian Church Speaker Forum (Feb. 23, 2003) (on file with author).

11. Carmen Denavas-Walt, Bernadette D. Proctor \& Cheryl Hill Lee, Income, POVERTY, AND HEALTH INSURANCE COVERAGE IN THE UNITED STATES: 2005 20-21 (2006), available at $\mathrm{http}: / / \mathrm{www} . c e n s u s . g o v / p r o d / 2006 \mathrm{pubs} / \mathrm{p} 60-231$.pdf.

12. DEP'T OF HEALTH AND HUMAN SERVS., UNDERSTANDING ESTIMATES OF THE UNINSURED: PUTTING THE DIFFERENCES IN CONTEXT 3 (2005), available at http://aspe.hhs.gov/health/reports/05/ uninsured-understanding-ib/ib.pdf (surveying income and program participants).

13. ROBERT WOOD JOHNSON FouND., Time to Stop Gambling With America's Health, http:/www. rwjf.org/about/president/featuredetail.jsp? featureID $=1603$ \&pctype $=577$; see also COMM. ON THE CONSEQUENCES OF UNINSURANCE, HIDDEN COSTS, VALUE LOST: UNINSURANCE IN AMERICA (National Academies Press 2003), available at http://newton.nap.edu/execsumm_pdf/10719.pdf [hereinafter HIDDEN COSTS] (discussing the economic and social costs of uninsurance).

14. Rob Roberts, Study: Targeted Fixes Can Dent Uninsured Census, KAN. CITY BUS. J., July 7, 2006, at 3, available at http://kansascity.bizjournals.com/kansascity/stories/2006/07/10/story4. html.

15. Kaiser Family Found., State Health Facts, Health Insurance Coverage of Nonelderly 0-64, http://www.statehealthfacts.org/cgi-bin/healthfacts.cgi (follow "Health Coverage \& Uninsured" 
A report from the Commonwealth Foundation found that almost two out of five Americans report "serious" or "very serious" problems paying medical bills. ${ }^{16}$ A function of income you say? Yes, but not as much as you would think. Serious problems paying bills were reported by half of adults in families with annual incomes of less than $\$ 35,000$, (as you may expect), but also by $33 \%$ of adults in families with annual incomes of between $\$ 50,000$ and $\$ 75,000$, and $21 \%$ of adults in families with annual incomes of $\$ 75,000$ or more. ${ }^{17}$

In the years since the earlier article was printed in the Milwaukee Sentinel, the percentage of full-time employees having any health insurance dropped from $92 \%$ to $65 \%$ among medium and large businesses, and from $69 \%$ to $42 \%$ among small businesses. ${ }^{18}$ Among part-time employees of small businesses, participation in employee health insurance programs is holding steady over the years at about $6 \%$ of the employed workforce. ${ }^{19}$

What is going on with employer-based coverage? Since 2000, premiums have increased by $87 \%$, yet wages have risen by only $20 \%{ }^{20}$ Business analysts predict that in spite of the continuing transfer of everincreasing amounts of health care expenses to employees, by 2008 , the health care costs of most Fortune 500 companies will exceed their aftertax profits. ${ }^{21}$ Stated another way, within two years, most of our largest, most successful businesses will spend more on health care related costs than they will receive in after-tax profits.

How high will these costs get? In the midst of declines in insurance protection, Nobel laureate economist Robert Fogel predicts that by 2030 , $25 \%$ of our gross domestic product will be spent on health care, up from

hyperlink, then follow "Nonelderly (0-64)" hyperlink) (last visited Feb. 26, 2006).

16. Cathy Schoen et al., The Commonwealth Fund, Public Views on Shaping the FUTURE OF THE U.S. HEALTH SYSTEM 5 (2006), available at http://www.cmwf.org/usr_doc/Schoen publicviewsfuturehltsystem_948.pdf.

17. Id. at 7 .

18. EMPLOYEE BENEFIT RESEARCH INST., EBRI DATABOOK ON EMPLOYEE BENEFITS, tbls.4.1 a, 4.1b (2005), available at http://www.ebri.org/pdf/publications/books/databook/DB Chapter\%2004.pdf.

19. Id. at tbl.4.6.

20. Kaiser Family Found. \& Health Research \& EduC. TRUSt, EMPloyer Health BENEFITS: 2006 ANNUAL SURVEY 6 (2006), available at http://www.kff.org/insurance/7527/upload/ 7527.pdf.

21. See Chart Focus Newsletter: Will Health Benefit Costs Eclipse Profits?, MCKINSEY Q., Sept. 2004, http:/www.mckinseyquarterly.com/newsletters/chartfocus/2004_09.htm ("Without cuts in expenditure or an economic boom, by 2008 the average Fortune 500 company may be spending as much on health benefits as it earns in profits."). 
about $16 \%$ today. ${ }^{22}$ In his words, health care will be the "driving force in the economy."

How is it that costs continue to soar while access to services and some health indicators, such as infant mortality, on which America ranks forty-third, two behind Cuba but just ahead of Croatia, decline $?^{24}$ How is it that over 18,000 of our fellow Americans die each year as a result of inadequate health insurance? ${ }^{25}$ How is it that American businesses continue to spend billions on health care benefits to maintain a system that directly contributes to their non-competitiveness in the world market, even as their employees take on greater financial burdens of their own?

The answer to these questions requires an understanding of where I feel the rhetoric of health reform locks horns with its reality, a proxy for the larger drama being staged in which divergent views of the world and directions for our country each compete for our favor. On this stage, health care is one of many plot lines-like education, energy, or national security-immersed in conversation aimed as much at hurting those with opposing viewpoints as it is at helping those whose individual circumstances are becoming increasingly perilous.

I don't have to spend much time explaining to you what these divergent views of the world are. They reflect our different ways of viewing "freedom": freedom from entitlements or freedom from wont? Freedom from government bureaucracy or freedom from market dangers and the growth of plutocracy? In his last State of the Union Address, President Bush used the word "freedom" twenty-one times, yet used the words "poor" and "poverty" just once. ${ }^{26}$ Contrast that to former Senator John Edwards' recent remarks to the National Press Club in which he used the term "freedom" once and the word "poverty" fifty-one times. ${ }^{27}$ The rhetoric of health reform begins with how our values are portrayed.

22. Gina Kolata, Making Health Care the Engine That Drives the Economy, N.Y. TIMES, Aug. 22,2006 , at $\mathrm{F} 5$.

23. Id.

24. See Cent. Intelligence AGENCy, The World Factbook: Rank ORder-INFANT MORTALITY RATE (2007), https://www.cia.gov/cia/publications/factbook/rankorder/2091 rank.html (listing infant mortality rates of countries in descending order but excluding countries for which such information is unavailable).

25. HIDDEN COSTS, supra note 13, at 5.

26. News Release, The White House, President Bush Delivers State of the Union Address (Jan. 31, 2006), available at http://www.whitehouse.gov/news/releases/2006/01/print/20060131-10.html.

27. Senator John Edwards, National Press Club Policy Address, Remarks as Prepared for Delivery (Jun. 22, 2006), http://johnedwards.com/news/speeches/20060622/. 
Let's examine these values further, using the last presidential election as a starting point. Mr. Kerry's positions on health care were very ambitious, rooted in tenets of justice that built upon expanded access to insurance for children and small businesses. ${ }^{28}$ Mr. Bush's positions were more closely tied to his goals of freedom and selfdetermination, promoting ways for persons with resources to spend them on health-related expenses. ${ }^{29}$ I didn't hear from either candidate the message that I felt all Americans needed to hear at the time, namely, "here is a plan that you can understand, a plan that we can all afford, and a plan that is available to all." Mr. Bush espoused virtually nothing in his plan that was not ideological in nature: association health plans, tax credits, health savings accounts, and greater funding for community health centers. The first three represented what for years had been considered largely unpopular and unproven free-market strategies, transferring health insurance dollars from some employers, employees, and the government to banks, mostly for-profit insurance companies, and large businesses. The fourth, providing more money to community health centers, was meant to address our uninsured problem, expanding funding to bare-bones safety net clinics that provide basic medical services to low-income people regardless of insurance status. As a counter balance to the other three policies, community health centers appeared to be the safe guard for people to fall back on if these marketdriven ideologies somehow didn't work.

Mr. Bush entered the campaign having already expended most of his political health capital on Medicare reform in 2003. The Medicare Drug Improvement and Modernization Act of 2003 (MMA) included a prescription drug benefit sold as a $\$ 400$ billion program over ten years but whose costs are now estimated at closer to $\$ 1.2$ trillion. ${ }^{30}$ It has been characterized by advocacy groups as a hand out to drug and insurance companies. ${ }^{31}$ Intended to provide older Americans and low-income

28. See Robert E. Moffit, Nina OWCHAREnko \& EdMund F. Haislmaier, The Heritage Foundation, Details MatTER: A Closer LOOK at SENATOR KERRY'S HEALTH CARE PLAN 8 (Oct. 12, 2004), available at http://www.heritage.org/Research/HealthCare/bg1805.cfm (noting that under Senator Kerry's plan, the government would assume full cost of children enrolled in Medicaid and expand coverage to working parents).

29. See News Release, The White House, President Bush Discusses Quality, Affordable Health Care (Jan. 28, 2004), available at http://www.whitehouse.gov/new/releases/2004/01/200401282.html ("The best way to empower citizens is to let them save and spend their health care dollars as they see fit.").

30. Ceci Connolly \& Mike Allen, Medicare Drug Benefit May Cost \$1.2 Trillion, WaSH. POST, Feb. 9, 2005, at Al.

31. See Families USA, Prescription Drugs, http://www.familiesusa.org/issues/prescriptiondrugs/ (last visited Jan. 1, 2007) (directing consumers to articles discussing the problems with 
persons with disabilities with a new form of prescription drug coverage, the MMA also features large gaps in coverage, so-called "donut holes," billions in subsidies to HMOs to expand their enrollment of seniors in managed care plans, and billions more to employers to encourage them to retain drug coverage for their retirees. Recent efforts by federal officials to put lower-than-expected premium costs charged in the first two years of this program in the best light ${ }^{32}$ hide the double-digit increase in the costs of prescription drugs that consumers still have to pay. Part of the reason for this cost increase is the inability of government to negotiate for prescription drug purchasing and the high co-pays or deductibles associated with this narrowed coverage. As an illustration, the House Committee on Government Reform released a report in November 2005 comparing average Medicare Part D and Department of Veterans Affairs (VA) costs of ten of the most popular non-generic drugs prescribed for seniors-drugs such as Advair, Celebrex, Nexium, Lipitor, and Zocor. ${ }^{33}$ The average price of a month's supply of these drugs purchased through Part D came to $\$ 116$, compared to the $\$ 63$ that it costs the federal government under the VA, with veterans themselves paying $\$ 80$ ( $\$ 8$ per prescription per month) for ten prescriptions to help defray the cost of the overhead. ${ }^{34}$ Using this example, not including the costs of premiums and other consumer costs such as co-pays and deductibles, Part D is at least $84 \%$ more expensive than existing federal purchasing. ${ }^{35}$

Beyond the rhetoric of choice were the realities of a Bush health plan in which visible benefits affecting large segments of voters, such as use of the Part D drug plan or greater access to HMOs, were promoted as a kind of Trojan Horse to advance mostly untested, market-based initiatives, with all this occurring at enormous federal cost.

We shouldn't believe-in hindsight-that John Kerry's plan addressed the problem directly either, with its arcane web of politically untenable and complicated schemes. In the end, it proposed infusing

Medicare drug plans).

32. See News Release, U.S. Dep't of Health \& Human Servs., Medicare Releases Data on 2007 Drug Plan Options, (Sept. 29, 2006), http://www.hhs.gov/news/press/2006pres/20060929.html (discussing new Medicare options designed to save seniors more money on prescription drugs).

33. U.S. HOUSE OF REPRESENTATIVES COMM. ON GOV'T REFORM-MINORITY STAFF SPECIAL Investigations Div,, New Medicare Drug Plans fail to Provide Meaningful Drug Price DiscounTs 5 (2005).

34. See id. at 6 (quoting the average "price for a one-month supply of each of the ten drugs" considered in the report).

35. Id; see generally FAMILIES USA, BIG Dollars, LitTle Sense: Rising Medicare PRESCRIPTION DRUG PRICES (2006), available at http://www.familiesusa.org/assets/pdfs/BigDollars-Little-sense.pdf (analyzing the effect of drug prices set by Medicare Part D plans). 
massive amounts of federal dollars directly into the same flawed system we have now. It was an unapologetic free-enterprise approach to expanding insurance, yet was pilloried by Mr. Bush, Mr. Cheney, and their spokespersons as yet another big government takeover.

While Mr. Kerry's dual goals of assuring insurance for most children and reducing health insurance rate increases were laudable, the path to getting there would have been filled with minefields. Resurrecting health reform in the shadow of an already depleted federal budget, redirecting political capital away from what even in 2003 seemed to many of us an endless war, and "health care fatigue," where most of the public grew tired of hearing words like "access" or "beneficiary," all weighed against Mr. Kerry. Polls showed health care as the fifth most important issue to voters at the time of the 2004 election. ${ }^{36}$ More recent polls, such as the New York Times/CBS News poll in July 2006, indicate that health care has now dropped to seventh in overall importance, with only $3 \%$ of Americans considering it the most important issue facing the country today. ${ }^{37}$ Earlier surveys put the issue of the war in Iraq in the lead by a considerable amount, followed in most cases by the economy. ${ }^{38}$ In addition, one side effect of legislation like the MMA-684 pages of deadening confusion-was to distance the general public further from engaging with health care. It would have been very difficult to garner public support for a Kerry health plan that had so many jagged edges, yet that was the default two years ago. I took Senator Kerry's slogan that "America can do better" as my personal hope that we could start by moving health care to where it belongs on the political agenda, ahead of gay marriage and tough-guy posturing. Of course, this proved not to be the case. In a half-hour speech in Georgia the first week in September 2006 before the anniversary of the actual day, President Bush used the term " $9 / 11$ " thirty-six times. ${ }^{39}$ This word use rose to a deafening crescendo in the weeks preceding the mid-term elections of 2006, with New Jersey's high court decision regarding benefits for gay couples giving the president additional fuel in his efforts to keep gay marriage

36. CNN.com, Election 2004 Exit Polls, http:/www.cnn.com/ELECTION/2004/pages/results/ states/US/P/00/epolls.0.html (last visited Jan. 5, 2007).

37. The New York Times/CBS News POLL: September 15-19, 2006 (2006), http://graphics8. nytimes.com/packages/pdf/politics/20060919_poll_results_sub.pdf, 4.

38. See generally PollingReport.com, Problems and Priorities, http://www.pollingreport.com /prioriti.htm (last visited Feb. 26, 2007) (detailing results of various polls).

39. News Release, The White House, President Bush Discusses Progress in the Global War on Terror (Sept. 7, 2006), available at http://www.whitehouse.gov/news/releases/2006/09/print/ 20060907-2.html. 
squarely centered in our daily thoughts. ${ }^{40}$ So where does this leave us today?

The National Procrastinator Club, announcing their annual convention postponement, likes to point out in their press releases that the problem we gnash our teeth over Monday is frequently forgotten by Friday. In some respects, my colleague Bob Lee's analogies to what he calls the "Italian Model," where governments continually collapse before they can be fixed or reformed, dove-tails with this procrastinator's way of looking at health reform. By putting off meaningful reform as long as we have, I feel we are inching closer to the inevitable collapse of the entire system. Employers continue to hold up the levees for now. But in response to recent global and domestic economic pressures, they are dropping health insurance coverage for growing numbers of retirees and employees, with the effect of slowly setting in motion events that will eventually require government to act-or react - to protect both the overall health of the public and the economy. As we've observed through a number of social movements in our country, once pain hits the middle class, things will happen. Poor health care hasn't yet hit the middle class as hard as it will when businesses abandon or diminish health insurance coverage for employees and retirees en masse, a trend accelerated by Ford's recent decision to eliminate health insurance coverage for Medicare-eligible retirees and their dependent children starting in 2008 , while raising premiums by $30 \%$ for current workers. ${ }^{41}$ The tipping point, I feel, is getting close.

In spite of short-term hardships, there are benefits of an Italian approach to social change. Having dodged most serious health reform efforts since 1965, we may now be facing-in 2007-our best opportunity to link public health and its underlying values of prevention and preparedness to broad health reform in ways that may never have been possible under Clinton's "Managed Competition," Nixon's wage and price controls, or Carter's business mandates. With increased visibility, public health issues such as environmental degradation, disease outbreak, violence, resource scarcity, and obesity and its effects threaten not just our health status but our country's place in the world. The advantage to dealing with these threats now, as opposed to earlier, is that most reform proposals will likely recognize the need to link health

40. See Christine Vestal, Gay Marriage Ripe for Decision in 3 Courts, STATELINE.ORg, Mar. 1, 2007, http://www.stateline.org/live/details/story?contentld=20695 (detailing national election results where several states addressed banning gay marriage with constitutional amendments).

41. David Shephardson, Ford Slashes Benefits: No Raises, Big Health Care Cuts for Salaried Staff, DETRoIT NEWS, Nov. 2, 2006, at 3A. 
services delivery (ways of delivering health care) with public health (ways of maintaining population health) through approaches that emphasize principles of prevention and behavioral change. Through past inaction we may now be better positioned to link economic and social benefits in ways that maintain health more and exclusively treat sickness less. All is not lost.

What issues will drive this convergence of medical delivery and public health? I feel that three stand out:

1. Management. We need to find ways to manage our public programs such as Medicaid, children's health screening (EPSDT), Medicare, and the State Children's Health Insurance Program (SCHIP) smarter and more efficiently. This will come down to reallocating priorities. A strong consumer voice is important here to help influence policy decisions that go into investing in our health and medical infrastructure. Insurance means little when nobody is available to treat patients or to run the system intended to drive it. I have been told that almost $40 \%$ of the workforce at the Centers for Medicare and Medicaid Services (CMS), the agency running Medicare and Medicaid, will be up for retirement in the next two years. Physicians and nurses in rural and inner city areas are in short supply. We need to retain stewards of our nation's health by investing in better management.

2. Chronic Disease Prevention. Prevention is the catalyst for any real effort to lower rates of chronic diseases such as diabetes, asthma, and cardiovascular-related illness. We need to find better ways to help the public practice prevention by creating incentives to help people minimize their risk of acquiring chronic diseases and to help physicians and other providers get paid not just for treating illnesses but also for maintaining people's health.

3. Preparing for and Controlling Infectious Diseases. I recently heard Pulitzer Prize winning journalist Laurie Garrett, author of Betrayal of Trust: The Collapse of Global Public Health, ${ }^{42}$ predict that even with all existing preparation, we can anticipate at least twenty-two million deaths in the U.S. when H5N1 Bird Flu gets here. Over 30,000 die annually from more ordinary flu bugs. ${ }^{43}$ AIDS is on the rise again, and our ability to control diseases is now shadowed in large part by our national response to Katrina. The ability to monitor outbreaks, (2000)

43. Dep't of Health \& Human Servs., Ctrs. for Disease Control \& Prevention, Key Facts about Influenza and the Influenza Vaccine, http://www.cdc.gov/flu/keyfacts.htm (last visited Jan. 23, 2007). 
vaccinate, educate, or in other ways protect and control-such as quarantine when necessary-is a state and local necessity, increasingly embraced by all forms of insurance plans seeking to minimize their own financial risks.

There are other public health issues that drive our approach to health care as well: obesity and its effects; health disparities among racial and ethnic groups, wealthy and non-wealthy, urban and rural, young and old; the insidious influence of tobacco; and the increase in violence and injuries, especially among youth. Tied to all these population risks are the individual risks of diminishing affordability of health insurance of any kind amidst the development of new forms of health insurance, like the Part D drug benefit, that no longer serve as an asset protection to beneficiaries or their families.

In the face of these increasingly acute public health challenges, our existing health care system accelerates towards collapse: and amidst pressures pulling us in one of two directions reflecting two disparate views of the world, we are faced with a new set of options for health reform. These options represent less of a clear choice between the rhetorical touch-points of justice and freedom presented to us in our last presidential election, and more of a continuum hosting elements of each of these values across an expanding middle ground from which I feel change will ultimately evolve.

Let's start at either end of the continuum first, with a single payer system on one end and vouchers on the opposite end.

The single payer option is modeled after the Canadian health care delivery system, in which one government entity underwrites the cost and administration of providing health insurance for everyone. Many people feel that by extending our current Medicare program to cover all persons in our country, rather than just persons ages sixty-five and older with a work history and persons who qualify for federal disability benefits, or by extending our VA model to non-military facilities and persons with no military service, we can cost-effectively expand health service access to all persons currently uninsured, while gradually phasing out employer-based coverage. This approach is attractive for a few reasons: it is relatively simple to understand; there are a number of models from around the world where it has been in place for many years; it would release businesses of their current health administration burdens; and it would be less costly, though probably not as inexpensive as some of its most vocal proponents suggest. Most Western European countries, Canada, Japan, and Australia, are moving away from this 
model in its purest form in part because administrative costs keep rising in efforts to maintain access and improve quality, ${ }^{44}$ at the same time that federal policy makers such as Jim McDermott of Washington, John Conyers of Michigan, and others propose a national single payer system in our country every year. Why hasn't it happened here yet?

Historically speaking, it could be argued that Senator Edward Kennedy and George Meany have done more to sabotage single payer systems in our country than Bill Frist and Dick Cheney by pushing their Health Security (single payer) Plans at times and in ways that worked against any form of less comprehensive reform that may have led to a single payer system over time. While in the past I believed in the inevitability of a single payer system in our country once big business realizes that it is in its best interests, what I have witnessed more recently leads me to believe that American business may well never consider a single payer system in its best interests, preferring, as do GM and Ford, imminent bankruptcy or open class warfare to relinquishing what it considers one of its historic tools for controlling employee influence in how it runs business. The American corporate emperors may no longer be wearing clothes, but the only part of their bodies that appear chilled right now are their hands - their "cold dead hands"- that continue to cling to the quaint notion that what is good for only them is good for the country. What they've taken from Toyota and Honda management has largely been superficial, dismissing the ethos that makes these corporations successful as alien to a culture that they must define. Even those that appear to understand the problem resist a single payer system. In September 2006, Craig Barrett, Chairman of the Board at Intel, said that the U.S. health care system "is out of control, it's unstable, it's basically bankrupt, it gets worse each year and all we do is tinker around the edges when what we need are major fixes. ${ }^{45}$ He then went on to extol Wal-Mart's minimal health coverage as a model for what industry efficiency should look like. ${ }^{46}$ After announcing the recent elimination of Ford's health insurance for retirees, Ford's U.S. operations president Mark Fields proudly pointed to a new annual contribution of $\$ 1800$ to Health Savings Accounts for retirees that he felt should, along with

44. See generally BIANCA K. FROgNer \& GERARD F. ANDERSON, THE COMMONWEALTH Fund, MulTINATIONAL COMPARISONS OF HEALTH SYSTEMS DATA, 2005 (2006), http://www. cmwf.org/usr_doc/825_Frogner_multinational_comphltsysdata.pdf (comparing health care systems and performance in nine industrialized countries).

45. Intel: Chair Calls for Cost-Efficient U.S. Health Care System, AM. Health Line, Sept. 28, 2006, http://www.americanhealthline.com/article.aspx?s=37373.

46. $I d$. 
traditional Medicare, replace their previous health insurance. ${ }^{47}$ This was very similar to what DaimlerChrysler rolled out weeks earlier. The rhetoric is "major fixes," while the reality is anything but.

But private sector resistance is not the only reason universal coverage isn't in place here. Victor Fuchs, in his summary of health reform options in a recent article, cites the shortcomings of the single payer system as being more economic: opening access to all will generate a surge in demand which will likely exceed government's ability to effectively meet supply. ${ }^{48}$ Based on experiences of other countries, it is not as straightforward to administer as it appears. ${ }^{49}$ I also see the single payer system at odds with our current national values, results of the 2006 elections notwithstanding. In my lifetime, I don't feel we have ever had a greater distrust or cynicism towards government when it comes to doing anything related to social justice. It's not that we can't. It's not that we won't. It's just that, as of now, we wouldn't be "we" if we moved in this direction. Eliminate not-for-profit hospitals and agree on global budgets? I think that boat has left port for now. It may return some day, but I'm not sure when.

On the other end of the continuum is the option that reflects where I feel much of our national values are right now. The Cato Institute has funded work promoting health reform models which simply eliminate government from health delivery in all respects but one: providing money to people so they can purchase health care-the voucher option. ${ }^{50}$ Tied to this option are many ideas that this administration is especially fond of: Health Savings Accounts, the elimination of federal entitlements, expansion of technology to accommodate the need for more consumer information, corporate subsidies to maintain participation in health delivery, and freedom to choose, even when the options are difficult to discern. The single-minded assumption here is that the market can always do it better, and it can do it the best if government funnels money to big business to encourage its involvement-the model behind Part $\mathrm{D}$ and the MMA.

In addition to the doubts you have likely heard about the merit of vouchers and the unfair burden imposed on poor people and those unable

47. Ford Cutting U.S. White-Collar Benefits, MSNBC, Nov. 2, 2006, http://www.msnbc.msn. com/id/15533910/.

48. See generally Victor R. Fuchs \& Ezekiel J. Emanuel, Health Care Reform: Why? What? When?, 24 HEALTH CARE REFORM 1399, 1406 (2006).

49. Id. at $1406-07$.

50. For an overview of research and studies on the topic funded by the Cato Institute see http://www.cato.org/healthcare/index.html. 
to easily compete in the market given their age, native language, disability, or social caste, this approach to health reform also has almost a Pollyannish belief in the role that technology will have in transforming our health care system. If there is anyone easily able to quote me the price for a prostatectomy and assure me what quality of care I'd be getting for that price, I would appreciate hearing from you as soon as possible. Healthcare as a market commodity may be current gospel, but it isn't fact. We can't comparatively price procedures that require subjective translation of dozens of contingencies between patients and providers before a course of action is undertaken, regardless of whether everyone is wired, all hospitals convert to electronic medical records, or the perfect quality measure is created. Yes, of course improved use of technology is a worthwhile goal. I'm not arguing against improving our use of technology, but it has its limits. Addressing its complexities is beyond what I consider realistic in the next five to ten years. And without informed consumers-recall the earlier statistics I cited $^{51}$-this whole market-based vision of people empowered to pick and choose what's best for them reverts to a house of sand.

Variations of both the voucher and single payer approaches take us to the center of the health reform continuum. The plan described by Fuchs and Emmanuel, called universal health vouchers (UHVs), starts from a less social Darwinist premise: it is not so much about us trying to find our own health care, as it is us trying to find our own health insurance. ${ }^{52}$ They propose guaranteeing all persons a basic benefit structure similar to that of Western European countries, paid for by value-added taxes (VATs). ${ }^{53}$ Similar to approaches in countries such as Holland, England, or Denmark, services above this basic package would be available to all, purchased by individuals on their own with after-tax dollars. ${ }^{54}$ Would this create a two-tiered system in which wealthier Americans have better health insurance than those unable to afford additional coverage? Of course. Is this different from what we have now? It would be better in that all persons would have some insurance. It would be no different in that some would have better coverage than others. Unfortunately, this is one of those realities that any type of system will have to deal with: whether to ration care rationally, or to ration it irrationally, as we do now.

51. PollingReport.com, supra note 3; Zogby Int'l Tel. Poll, supra note 4, at 2-3.

52. See Fuchs \& Emmanuel, supra note 48, at 1407-08 (stating the general proposals and effects of UHVs).

53. Id. at 1407 .

54. Id. 
A number of states and municipalities are working on other reform initiatives within the center of this health care continuum, incrementally using any means available to expand access to services, control costs, and improve quality. The most notable and ambitious state taking on health reform is Massachusetts, California's efforts to move to a statewide single payer system notwithstanding. While varying in scope and depth, most states are moving forward with some combination of Medicaid expansions, individual mandates, employer contributions, tax credits, increased purchasing power, reinsurance for high-risk segments of the risk pool, and some forms of technology expansions to improve efficiencies and reduce fraud. The driving force for the Massachusetts experiment is "shared responsibility," which adroitly weaves policies that require compromises from all positions on the political spectrum. ${ }^{55}$ As a concession to the right, the state will require everyone who can afford to purchase health insurance to do so, starting July $1,2007 .{ }^{56}$ In deference to the left, any business with more than ten employees will be required to pay an assessment of $\$ 295$ per employee per year if it does not provide insurance for its workers. ${ }^{57}$ In addition are other items, such as sliding scale subsidies for families up to $300 \%$ of federal poverty level to purchase affordable insurance, special high deductible, low cost plans targeted to nineteen- to twenty-six-year olds, and merging individual and small business insurance markets with the use of a so-called "connector" to reduce premiums. While other states, including Kansas, and some cities, such as San Francisco, have proposals on the table to increase access and streamline systems, it seems to me that Massachusetts is alone in hammering out, with a lame-duck Republican governor who has presidential ambitions, and a Democratic legislature, the necessary compromises that will lead to meaningful changes under a guiding vision of health care for all. I find this encouraging.

How far can we run with shared responsibilities? Malcolm Gladwell last year wrote a brilliant piece in the New Yorker describing the fallacies behind the so-called moral hazard, another of the guiding principles behind Bush health reform. ${ }^{58}$ This principle assumes that people will give in to their "moral" weaknesses to seek health care when they don't really need it simply because it will be paid for by good insurance. It has

55. Stuart H. Altman, Can Massachusetts Lead the Way in Health Care Reform?, 354 NEW ENG. J. MED. 2093, 2093 (2006).

56. Mass. Dep't of Agric. Res., Health Care Reform Act of 2006, http://www.mass.gov/agr/ news/health_care_reform_act.htm (last visited Feb. 26, 2007).

57. Altman, supra note 55 at 2093.

58. Malcolm Gladwell, The Moral-Hazard Myth, NEw YorkER, Aug. 29, 2005, at 44. 
been used as justification for expanding ways that individuals cost-share their medical services, as well as ways to change insurance from being good to being just good enough to keep people out of bankruptcy if they need medical care- the Wal-Mart model.

More recently, in an article in the August 28, 2006 edition of the New Yorker, Gladwell examined the structural flaws behind maintaining employer-based coverage amidst a diminishing risk pool and rising costs, especially costs incurred by corporations that have to support nonproductive dependents of workers or former workers through guaranteed health insurance coverage. ${ }^{59}$ He talks about a "dependency ratio" of workers to non-workers, and suggests that Ireland's remarkable economic expansion is attributable to the demographics of many young workers, fewer children since contraception was legalized in 1979, and proactive government policies that relieve businesses of the burden of health care costs. ${ }^{60}$ Conversely, bulging retirements and government policies that place the pressure on companies to shoulder the costs of health care make it virtually impossible for older, larger American businesses like GM or Bethlehem Steel to ever be competitive in a global market again unless relieved of this liability. ${ }^{61} \mathrm{He}$ cites statistics showing that for every twenty-two people of working age now in Ireland, there are ten dependents. ${ }^{62} \mathrm{GM}$, by comparison, has about 141,000 workers, yet is responsible for paying benefits to 453,000 retirees alone. ${ }^{63}$ And like other older American corporations, this ratio is expanding daily.

Gladwell tracks our current situation to 1950 and negotiations between GM and the head of the United Auto Workers Union (UAW), Walter Reuther. Reuther, a staunch advocate of universal health care, gave in to GM's demands that UAW provide health insurance to auto workers at the time. He believed that by doing so, GM would eventually come to its senses and realize that what it was doing was so economically unsustainable that within a few years, it would recognize the fallacy behind collective bargaining and agree to regional purchasing of health care benefits at the very least, if not a national risk pool. ${ }^{64}$ It was a gamble that failed, in spite of the eerie accuracy behind Reuther's larger vision.

\footnotetext{
59. Malcolm Gladwell, The Risk Pool, NEw Yorker, Aug. 28, 2006, at 30.

60. Id. at 31 .

61. Id. at $33-35$.

62. Id. at 31 .

63. Id. at 33 .

64. Id. at 35 .
} 
The Citizens' Health Care Working Group, a national listening tour created by the same legislation that brought us the Part D prescription drug benefit, recently published five recommendations based upon thirtyone community hearings from across the country and thousands of Internet postings. ${ }^{65}$ The Working Group said that Americans wanted: (1) guaranteed financial protection against very high health care costs; (2) more integrated community health networks; (3) increased efforts at improving quality and efficiency of health care; (4) increased access and attention to end of life care; and (5) a core benefit package available to all Americans. ${ }^{66}$ These are good principles on which to continue a dialogue and, like the Massachusetts experiment, cause for optimism.

Two years ago, I spoke to a group of medical students and told them that the road to health reform in our country is through Baghdad. I tried to explain to them that by resisting the current war in Iraq, events could lead to unshackling the resources and political will needed for us to make changes in areas like health care that will increase our security where it will help us the most-here at home. I will never forget a comment of one of the medical students in the room that day when I challenged them to get involved and asked them to share ideas on how. After considerable silence, one young man said, "But when are we going to have the time to do this?" Indeed, where do we start?

In our current climate, we, the people who use health care services, need to organize in ways that give us a voice in health policy decisionmaking based upon our collective interests rather than the narrow professional or personal self-interests of those whose voices have dominated the past. In this I agree with Malcolm Gladwell that perhaps Walter Reuther's time has finally come. Whether it is through consumer health coalitions, health care forums like the Kansas Law Review Symposium, or through efforts of student organizations on campuses around the country that reach out to communities and health professionals, we have to find a way to make our voices heard. My message of hope is to get involved, either through a political candidate who can help change our current direction or through an organization that can help reestablish health care to where it belongs in the national agenda.

Through the last six years, the rhetoric of health reform has become as perverse and Orwellian as most other national political dialogue:

65. Citizens' Health Care Working Group, Health Care that Works For all AMERICANS 9-19 (2006), available at http://www.citizenshealthcare.gov/interimrecs/interim recommendations.pdf.

66. $I d$. 
"clean skies" now means more pollution; "no child left behind" means less school funding; "Brownie, you're doing a heck of a job" means, well, we all know what it means. Through the same looking glass, freedom to choose has become the key to finding solutions to our current health care crisis.

"The people are desperate and in need of proper health care, your majesty!!!"

"Let them have choice," said the Emperor.

The reality of health reform in our current climate is that we now have to take matters into our own hands, not unlike the way French republicans responded to this sentiment of disconnectedness with their leaders in 1793. As voters so clearly demonstrated in the 2006 mid-term elections, our own Republicans may benefit in 2008 from disassembling their guillotine directed towards the social insurance programs that the public clearly and consistently favors. If they can't, they run the risk of turning the blade on themselves once again in the next election.

It is not a time for consumers of health care to be silent and expect others to do right by us. We have to do what we can to rebuild a national health care agenda that sets a direction that will improve our health as it helps us keep pace with the rest of the developed world. It may require compromise; it may require sacrifice; it may require starting from positions I never imagined we would have to retreat to a few years ago. But I remain hopeful that it is possible, and I remain optimistic that this may lead to a comprehensive national health care plan while we still have time to design one. 